\title{
POSTPRINT
}

\section{Indexing Priority of Position: Eben as Response Particle in German}

\author{
Emma Betz a and Arnulf Deppermann b \\ aDepartment of Germanic and Slavic Studies, University of Waterloo, Canada; ' $I n s t i t u t$ für Deutsche Sprache, \\ Germany
}

\begin{abstract}
Response particles manage intersubjectivity. This conversation analytic study describes German eben ("exactly"). With eben, speaker A locally agrees with the immediately prior turn of B (the "confirmable") and establishes a second indexical link: A relates B's confirmable to a position A herself had already displayed (the "anchor"). Through claiming temporal priority, eben speakers treat a just-formulated position as selfevident and mark independence. Further evidence for the three-part structure "anchor-confirmable-eben" that eben sets in motion retrospectively comes from instances where eben speakers supply a missing/ opaque anchor via a postpositioned display of independent access. Data are in German with English translation.
\end{abstract}

Responses are central to managing intersubjectivity in interaction (Thompson, Fox, \& Couper-Kuhlen, 2015). Through their design and placement, interactants show their understanding of the current action and the larger activity in which they are engaged, index alignment or agreement, and manage relative epistemic positioning. Extract 1 shows an instance of the type of responsive turn in focus. ${ }^{1}$ It is taken from a room remodeling project, during which Pauline $(\mathrm{PZ})$ is engaged in painting and Tamara (TZ) offers a positive assessment of the emerging result (01). Pauline responds with two particles, $j a$ and eben (03), and an explicit knowledge formulation (05).

Extract 1: streifen (“[brush]lines”) [126.av_FOLK_218_c654_16:45]

01

TZ: nee=sieht doch cooler aus ohne die streifen: no ((it)) does look cooler without the lines

02 (0.2)

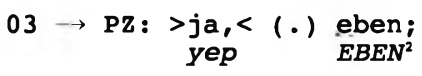

04 (0.1)

05

PZ : wusst ich auch:

I also knew ((that) $)^{3}$

\footnotetext{
CONTACT Emma Betz_embetz@uwaterloo.ca

Department of Germanic and Slavic Studies, University of Waterloo, 200 University Avenue West, Waterloo N2L 3G1, Canada.

Color versions of one or more of the figures in the article can be found online at www.tandfonline.com/hrls.

We thank Veronika Drake, Andrea Golato, and Julia Kleiner for additional data examples, three anonymous reviewers for valuable commentary on earlier drafts, and Thomas Parker and Laura Kronauer for copyediting. All remaining errors are ours.

${ }^{7}$ This extract will be analyzed in a later section as Extract 7.

${ }^{2} \mathrm{~A}$ cross-linguistic comparison would be necessary to identify functional equivalent(s) in English. A candidate would be English exactly (possibly a specific prosodic realization with strong prominence on the second vowel), but since there is not yet enough research for such a comparison, we refrain from translating eben.

${ }^{3}$ Double parentheses in the translation are used for words that need to be added to make the translation more idiomatic, e.g., objects of a transitive verb or subject pronouns. Single parentheses are used for uncertain hearings and also for approximations of difficult-to-transfer elements, such as modal particles.
} 
This article focuses on the German response particle eben. ${ }^{4}$ We will show that eben is used for confirmation and that it orients both toward the prior turn and the larger interactional history. The specific way in which it does this is different from other response tokens. Our analysis shows that eben is used in a three-part discourse-deictic structure: It reactivates more distant prior talk and relates it to the just-prior turn. To frame our analysis, we discuss relevant work on response particles in interaction, focusing on work that shows how response particles invoke the relevance of prior talk.

\section{Response particles in interaction}

German eben is used as a confirmation particle. ${ }^{5}$ In confirming, participants manage agreement but also negotiate access to and relative authority over knowledge (Heritage \& Raymond, 2005; Schegloff, 1996a; Sorjonen, 2001). The present study shows how participants manage stance in responding to "confirmables" (Betz, Taleghani-Nikazm, Drake, \& Golato, 2013) that formulate an aspect, presupposition, or upshot of a preceding turn. ${ }^{6}$ Confirming can be seen as a retrospective practice. Such practices "create coherence between current and past activities, and they are indispensable for displaying understanding and accomplishing intersubjectivity" (Deppermann \& Günthner, 2015, p. 4). Confirming specifically entails a claim to prior knowledge and/or independent positioning: It indexes what was heard as not new. ${ }^{7}$ In Extract 1 , streifen, a claim to independent knowledge is explicitly formulated (line 05), but response particles themselves can convey such claims. Research has shown that epistemic positioning (What kind of knowledge is confirmed? What type of access is claimed?) is essential in the choice of confirmation format if different particles are available. German genau, for example, marks agreement, correctness, or appropriateness while claiming independent access if it is used in response to confirmable turns, informings, and collaborative completions (Betz, 2014; Oloff, 2017). After turns designed as informings, second-position genau can also convey epistemic competitiveness. ${ }^{8}$ We will argue that eben is similar to this latter use of genau: It conveys agreement with a prior turn while flagging an incongruity in relative positioning. Our analysis will also show, however, that eben differs from genau in its discourse-deictic structure and thus in the kind of retrospective orientation, or backlinking, it establishes.

Backlinking practices can "skip-connect" (Sacks, 1992, pt. II, p. 349) across significant distances, thus reactivating the relevance of prior talk and courses of action. Research on turn-prefacing illustrates this: Bolden $(2006,2008)$ shows that so-prefacing links an action about to be launched to an overarching agenda: Speakers of English use turn-initial so to reintroduce previously interrupted or abandoned interactional moves and forwards pending interactional agendas. English stand-alone so (Raymond, 2004) links back to prior talk by projecting (but not formulating) an upshot of it, and this upshot is a recipient's action. So prompt this next action, thereby connecting local conduct to larger sequential and topical trajectories. Our analysis shows that, in a similar way, responsive eben conveys participants' sense of interactional history beyond the immediate, adjacent context. We will thus argue that eben cannot be analyzed without taking into account the larger

\footnotetext{
${ }^{4}$ German also has an adjective ("even," "smooth"), temporal adverb ("just now"), and modal particle eben. The particle is described as indexing "'recourse' to facts mentioned before or assumed to be known to the hearers" (Lütten, 1979, p. 30) and thus as essentially backward-looking, reflecting an etymological connection to the semantics of the temporal adverb. Moreover, the modal particle is said to convey unquestionable facts in assertions, thus (re)establishing consensus (Lütten, 1979, p. 33). Zifonun, Hoffmann, and Strecker (1997, p. 1231) note that it regularly marks assertions as consequences of previous talk, particularly in suggestions or advice giving. Our analysis will show that the response and modal particle thus share some semantic-pragmatic features: Both indicate consensus while highlighting something as not new.

${ }^{5}$ On response particles that can be used for confirmation in English, see Barnes (2011, 2012); Gardner (2007); Heritage (1984, 2016); on German, see Barth-Weingarten (2011); Betz (2015); Golato and Fagyal (2008); Oloff (2017).

${ }^{6} \mathrm{Cf}$. "confirmable turn" by Barnes (2012). Note that we are using "confirmable" as an action-based and essentially retrospective category. It is a turn that was treated by recipients as confirmable.

"But see Küttner (2016), who proposes a somewhat narrower definition of what should be understood as "confirmable": propositions that "the recipient (the would-be confirmer) has, or can legitimately claim, epistemic supremacy relative to the other participant ... over the issue at hand" (p. 54).

${ }^{8}$ For related work on American English right, Australian English that's right, and partial confirmatory repeats, see Barnes (2012), Gardner (2007), Küttner (2016), and Stivers (2005).
} 
activity context and, sometimes, considerable interactional history. To further contextualize our findings, we summarize research on response tokens as backlinking devices in different languages.

Response tokens can index the relevance of the larger course of action and thus operate on different discourse levels (Gardner, 2007; Golato \& Betz, 2008; Heinemann, 2016; Mazeland \& Plug, 2010; Sorjonen, 2001). The fit of the just-prior turn within the larger course of action can be addressed with multiples in different languages (Barth-Weingarten, 2011; Golato \& Fagyal, 2008; Heinemann, 2016; Stivers, 2004). For Danish, Heinemann (2016) shows that nânå differs from single nâ in that it registers the prior turn as a revision of an earlier turn by the same speaker. This illustrates that "the distinction between just addressing the prior turn on one hand, and addressing the larger course of action implemented in that turn" (Heinemann, 2016, p. 61) is relevant for participants. The German particle-adverb combination achso as an epistemic marker also invokes the relevance of the larger sequence (Golato \& Betz, 2008). Signaling that "the immediately prior talk has been produced as connectable to, or building on, some earlier talk" (Gardner, 2001, p. 57) is a function of right in Australian and British English, marking the talk to which it responds as "advancing the epistemic store of the Right producer" (Gardner, 2007, p. 336) and thus the shared common ground (see Clark, 1992).

While right marks a link between two pieces of information by another speaker, we will show that eben connects the prior turn with something the eben speaker herself had said before. Sorjonen (2001) describes one function of Finnish nii as connecting to a prior turn by the nii speaker herself. She shows that third-position nii, in sequences in which speakers negotiate mutually known matters, embodies a particular type of agreement with a prior stance taking: marking the prior as "something that the nii speaker had conveyed or implied in his or her own prior turn" (Sorjonen, 2001, p. 195). This amounts to "reasserting one's own prior stance" (Sorjonen, 2001, pp. 195-199) after a coparticipant's indequate stance display (e.g., a downgraded second assessment, a news receipt instead of an agreement) and leads to sequence expansion. These are thus disagreement-implicative contexts. We will show that German eben is similar to nii in that it connects to a prior turn by the nii speaker herself, but in contrast to Finnish nii, ebenis not limited to disagreement-implicative contexts. The connection eben indexes has, to our knowledge, not yet been described for response particles in any language.

\section{Data}

he data comprise approximately 220 hours of videotaped face-to-face and audiotaped telephone interactions between German speakers from different geographical areas. They include everyday, public, and institutional interactions. Activities include playing games, preparing and eating meals, assembling furniture, updating family and friends in transatlantic calls, "interviewing" a prospective roommate, coaching job seekers, classroom interactions, driving lessons, and oral university exams. Contexts also include workplace meetings, theater practice, guided museum visits, public mediation talks, and radio phone-in programs. Data are taken from the publicly accessible FOLK corpus of the Institute for the German Language in Mannheim, Germany (http://dgd.ids-mannheim.de) ${ }^{9}$ and the authors' private corpora. All were collected with the informed consent of those involved and have been anonymized.

Transcripts include the original German, using Jeffersonian notation (Hepburn \& Bolden, 2013), and an idiomatic English translation. Our transcription of embodied conduct follows Mondada's conventions for multimodal transcription. ${ }^{10}$

Our analysis is based on a first close analysis of an initial collection of 42 examples across a variety of contexts (face-to-face and telephone interactions) and a second round of analysis of a larger collection of 290 instances of responsive eben. ${ }^{11}$ We analyzed mundane and institutional interactions separately, but

\footnotetext{
${ }^{9}$ This corpus FOLK 2.8 comprises, as of May 2017, 279 hours of informal, institutional, and public interaction (259 recorded interactions, 1.95 million word tokens).

${ }^{10}$ See https://franz.unibas.ch/fileadmin/franz/user_upload/redaktion/Mondada_conv_multimodality.pdf.

${ }^{11}$ The total number of eben in FOLK 2.8 is 2,298, comprising 1,917 occurrences as modal particles, 290 response particles (12.6\%), 80 temporal adverbs, two attributive, and 0 predicative adjectives. Numbers are based on manually checked, automatic POS searches.
} 
our general description of the practice holds across contexts. Our account therefore does not separate these contexts. Instead, we distinguish two types of overall structures in which eben is embedded: eben with (section "Prior display") and without (section "Postpositioned evidence") an explicit prior positioning display to which it can backlink.

\section{Analysis: The basic structure in which eben is embedded}

Extract 2 illustrates the core features of responsive eben. It shows how speakers use eben to reactivate an earlier positioning display related to the local (just-prior) turn. Extract 2 is taken from a telephone conversation between Kirsten (KI) and her sister-in-law Rita (RI). Kirsten is currently completing a graduate degree in North America. We join the conversation as Kirsten is explaining why she has to cancel a visit to Germany: She has to prepare for exams (lines 03, 05-06, 08) and is lacking funds to travel (line 07). After an assessment of her current situation as total schwer ("super difficult"), Kirsten produces a potentially sequence- and topic-closing formulation (13).

Extract 2: prüfungen (“exams”) [12.tel.pruefungen_AG_Kirsten_1_23:30]

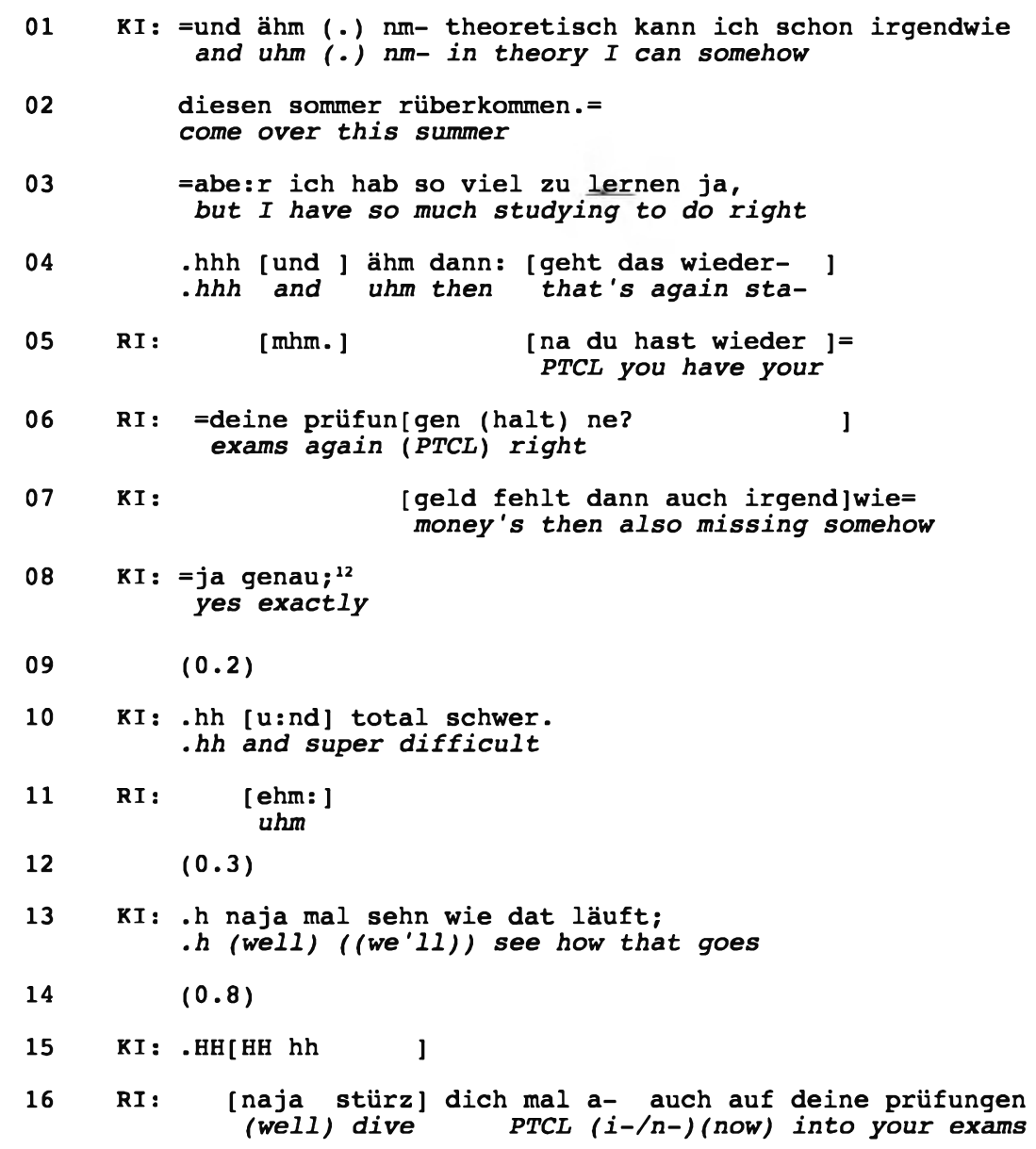

\footnotetext{
${ }^{12}$ Kirsten's ja genau responds to line 06 , which is a request to confirm a fact in her domain. It confirms (a) the fact that Kirsten has exams coming up and (b) its relevance for the argument Kirsten is building. Kirsten thus confirms Rita's understanding and aligns with the epistemic positioning put forward.
} 


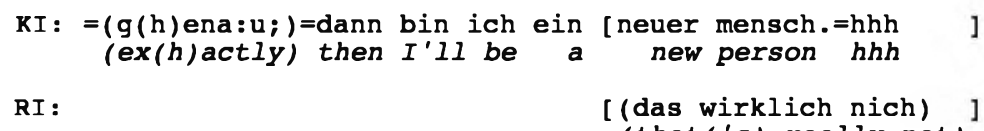

$(0.2)$

In lines 16-20, Rita accepts Kirsten's account and the apology it implements. She first formulates the advice that Kirsten focus on exam preparation (line 16), thus endorsing the course of action Kirsten has already chosen (lines 01-03). Additional reasons supporting this course of action follow. In line 21, Kirsten receipts them with genau, which indexes an independent agreeing stance (Willkop, 1988, pp. 139-140; cf. Oloff, 2017), and adds that she will feel like "a new person" once she has passed her exams. This self-focused, description adds a(nother) beneficial consequence of following Rita's advice.

Rita responds with eben, in this case combined with ja: ("yes") (line 25). Here, eben receipts something to which Kirsten has primary rights. However, the turn that eben confirms (line 21) could be heard as reformulating a position that Rita herself had already conveyed independently (in lines 17-20). This puts Rita in a position in which she can do more than agree with Kirsten's turn (line 21): She confirms it as something inferable from her own prior talk. Rita's eben thus operates on two discursive levels: It makes a local connection (agreement with prior turn) and simultaneously establishes a more global link between the prior turn and an earlier contribution by the eben speaker.

We argue that making this global connection is the distinctive work of responsive eben and that the global connection eben establishes indexes epistemic or argumentative priority. ${ }^{13} \mathrm{We}$ understand "priority" in a temporal sense as "prior-ness": the eben speaker indexes that she had herself already communicated what was just formulated by the coparticipant-thus orienting to the coparticipant's responsibility for correct interactional bookkeeping, i.e., to know things that have already been said or conveyed (Schegloff, 1991, p. 164). We call the point to which eben backlinks (and which it thereby reactivates as relevant) the discursive anchor. Eben is embedded in the following three-part structure:

(1) anchor, produced by speaker A (lines 17-20 in Extract 2): A display of a position or knowledge. We use the term anchor instead of antecedent because this turn is not

\footnotetext{
${ }^{13}$ We adopt the term from Heritage and Raymond (2005), who discuss "priority" in assessment sequences as central to negotiating "who is agreeing with whom" (Heritage, 2013, p. 383): "[B]eing the first to offer an assessment of some state of affairs carries an implicit claim of epistemic priority" (Heritage, 2013, p. 380). Both first and responding speakers can push back against the epistemic implications of sequential position. Epistemic priority and superiority are two facets of epistemic primacy and connected to authority (Hayano, 2013, p. 21). We use "priority" in a strictly temporal sense, as claiming to have conveyed knowledge/a position before. In the contexts in which eben is used, (temporal) priority may or may not be connected to matters of superiority for interactants. We thus separate the two concepts and use "priority" in a narrower sense.
} 
coreferentially but inferentially related to the subsequent formulation by $\mathrm{B} .{ }^{14}$ The inferential relation could be cause/consequence, general/specific, or via presupposition. The relevance of this turn, that is, its status as anchor, only emerges with the subsequent use of eben.

(2) confirmable, by B (dann bin ich ein neuer mensch ("then I'll be a new person"), line 21): an aspect, presupposition, or upshot of the anchor, e.g., supporting evidence for another speaker's position. The confirmable is either adjacent to the anchor or, more commonly, at a distance (see section "Remote anchors"). It is within the same topical talk, although not necessarily within the same conversation (see Extract 7). The confirmable never repeats the anchor.

(3) eben turn, by A (line 25): responsive and adjacent to the confirmable. Eben can constitute the whole turn or combine with other particles, the most common being ja/jo, genau, jaja, $n a$, and nein/nee. It can be doubled and may be followed by more talk. Eben expresses agreement and priority of positioning: It connects confirmable and anchor inferentially, thus indexing that the position just formulated by $\mathrm{B}$ is consistent with/inferable from a position conveyed by A herself. ${ }^{15}$ The specific anchor and the way in which the confirmable follows from it have to be inferred by $\mathrm{B}$. Indexing priority with eben can contribute to additional, context-specific functions-for example, marking a coparticipant's justreached insight as delayed (Extracts 7 and 10) or legitimizing an explicit rejection of a coparticipant's self-positioning (Extract 3).

Our analysis focuses on the double indexicality of eben-that is, the specific backlinking it enables speakers to do, rather than its implications for alignment. Eben itself does not implement a distinctive prospective expectation; rather, the sequential development after eben reflects the relevancies of the larger sequential, topical, and argumentative structures in which confirmable +eben are embedded.

Extract 2 illustrates the basic structure of eben use within a compact sequence. ${ }^{16}$ While the confirmable and eben turn are always sequentially adjacent in our data, the anchor does not have to be. It can be within the local sequence, further removed within the current conversation, or in a prior interaction. We speak of a "three-part structure" to capture how eben indexically links confirmable and anchor, producing a discoursedeictic connection. In this abstract structure, eben appears as the third element, but it is not a sequentially third-positioned item. Rather, eben is used responsively in second position to the confirmable that structurally provides for epistemic and evaluative positioning. The "participants' work" (Jefferson, 1972, p. 315) in using eben in this position over other possible response particles is to mark the confirmable as not new. Specifically, participants agree with the just-prior turn but take issue with the epistemic balance it suggests, thus reinterpreting the discourse-so-far in a particular way. In the process, eben emerges as a third element in a more global structure.

The next sections show how the basic structure illustrated in Extract 2 can be varied. The main parameters of this variation are the presence/absence of an explicit anchor, the distance between anchor and confirmable (proximal or remote), and the presence/absence of evidence after eben. We describe occurrences with and without an identifiable prior anchor and propose two distinct types of eben uses: prior display versus post-positioned display. We finally provide and discuss a quantitative overview of the different uses we found.

\footnotetext{
${ }^{14}$ We adopt the term from Schwarz-Friesel (2007), who uses it in their analysis of "indirect anaphora." Like the turns confirmed by eben, indirect anaphora do not have coreferential antecedents but connect back to a prior item or stretch of discourse that is only inferentially related to the anaphoric expression (e.g., by meronymy).

${ }^{15}$ We speak broadly of eben indexing "a position" rather than "knowledge." Eben typically reindexes a formulation of evaluative or argumentative stance, which could not aptly be termed "knowledge."

${ }^{16}$ For ease of reading, we explicitly mark the components "anchor" (A), "confirmable" (C), and "eben turn" (E) in all remaining transcripts and use them to structure our analyses. It should be kept in mind, however, that the anchor is not a sequentially first position; it only becomes salient with the use of eben.
} 


\section{Prior display: Positioning before eben}

We first discuss examples with an identifiable prior anchor. Extracts 3-8 show that eben can reindex a position taken in the same sequence, just prior to the turn that eben confirms locally (Extracts 3-5, section "Proximal anchors"), but that it can also backlink across significant discourse distance, as far as to a prior conversation (Extracts 6-8, section "Remote anchors") .

\section{Proximal anchors}

In Extract 3 friends are cooking together. EW, who is stirring food in a pot on the stove, has just described a vacation trip to Bolivia as so cool (line 01). DW, seated behind EW, then laments her own lack of spectacular vacation experiences (line 03). With this self-deprecating formulation, DW may be fishing for a disagreeing positive assessment (Pomerantz, 1978). Her self-positioning is receipted as an unwarranted complaint: EW withholds affiliation and then curtails an expansion of DW's action (line 07).

Extract 3: huskytour [154.av_FOLK_KOCH_300_c1017_15:12]

$01 \mathrm{EW}$ : das is so coo:l. that's so cool

$02 \quad(1.3)$

03 DW: +ich hab noch net so was ${ }^{\circ}$ cooles gemacht_ ${ }^{\circ}+=$ $I^{\prime}$ ve not done anything that cool yet +whiny voice-------------------------+

(a) 04 EW: $=[t ! a c h h ;]$ PTCL

05 CS: [ ${ }^{\circ}$ hähä॰ ]

$06 \quad(0.2)$

(a) $07 \mathrm{EW}$ : *komm $\mathrm{LA}^{*}+$ ber net, + come on chatter/blabber not come on stop whining

dw *head turn to DW*

(C) 08 DW: doch=ich hab schon auch ${ }^{\circ}$ coole sachen ge* [macht; ] PTCL I have PTCL also cool things done (yeah) I've also done cool things

(E) $09 \mathrm{EW}:$ head turn to sEBEN.]

$10 \quad(0.9)$

11 DW: das coolste was ich glaub ich gemacht hab= the coolest thing I think I've done

12 =war so ne huskytour in (.) in 1 [appland.]

$13 \mathrm{xW1}$ : was a husky tour in in lapland [ oah

14 CS : gei[l. so was is echt< ]= awesome that's a kind of

$15 \mathrm{EW}:\left[{ }^{* j A *}(\cdot) * *\right.$ siehst $d_{\uparrow} u$ ? ] $=$ yes (you) see **......palm up gesture tow. DW--> 


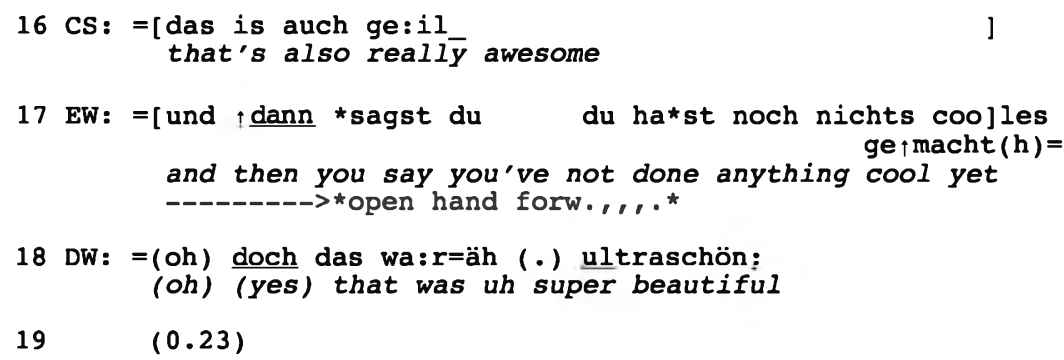

EW's dismissal of the basis underlying DW's complaint, that DW lacks "cool" vacation experiences, is already hearable in line 04 . The epistemic change-of-state ach (04) is primarily used as a turn-intial information receipt (Golato \& Betz, 2008; Golato, 2010), but it may also convey disagreement (Schwitalla, 2003, p. 156; Willkop, 1988). EW here rejects DW's assessment and thus her self-positioning as an unexciting person with $t$ !ACHh (ach combined with an alveolar $\operatorname{click}^{17}$ ).

The anchor. With $t$ !ACHh; komm laber net (04/07), EW explicitly marks DW's assessment of her own experiences as exaggerated and thus incredible. The discourse marker komm requests an activity shift by reference to the common ground of what normatively constitutes an appropriate action (Proske, 2014). This is supported by EW's ensuing explicit request to "stop whining" (LAber net).

The confirmable. In line 08, DW formulates a revision of her earlier position: DOch =ich hab schon auch 'coole sachen gemacht ("[yeah] I've also done cool things"). With doch (Helbig, 1988), DW marks the unfolding turn as responsive to line 07 and projects concession or back-down from her earlier position. The remainder of the turn not only revises DW's earlier position but makes explicit what was indexed by EW as common ground in line 07.

Eben turn. EW accepts DW's (revised) position while marking it as not new information. She does this by establishing an inferential connection between DW's revised claim and her own prior position (conveyed in lines 04/07). There is additional nonverbal evidence that eben marks interactants' positions as realigned: EW turns her gaze back from EW to cooking while uttering eben (line 09).

In this example, eben contributes to displaying criticism: EW is faulting her coparticipant for an unwarranted complaint and for failing to consider common ground, a failure DW remedied after her position and positioning were challenged. The interaction following the eben turn supports this analysis. DW furnishes evidence for her revised claim in lines $11-12$, EW receipts this as evident in line 15 (with the comment siehst $d u$ ("see") and a palm-up open-hand gesture; Kendon, 2004, pp. 264-281), and the continuation of EW's turn (line 17) reiterates the contrast between DW's earlier assertion (line 03) and her actual experience. This leads to another back-down by DW, who provides a revised assessment (line 18).

Extract 4 shows an example of eben in an instructional context: a secondary classroom on German literature. The teacher asks students to interpret the role of different characters in Lessing's Nathan the Wise. Eben is used in the evaluation slot of a teacher-initiated initiationresponse-evaluation (IRE) sequence (McHoul, 1978; Mehan, 1979), a common dialogic format employed in Western classrooms, especially when teachers engage the whole class-for instance, in reviewing material from a previous lesson.

\footnotetext{
${ }^{17}$ Wright (2011) shows that clicks demarcate the onset of new and disjunctive sequences in English. On the affective work of clicks after complaints in English, see Reber (2012).
} 
Extract 4: ringparabel ("ring parable") [55.av_FOLK_121_c227_04:56]

01 TE: das habt=ihr ja gmacht, (.) you've PTCL done ((=covered)) that

02 TE: ihr habt ja die:- (0.3) parabel gedeutet; you have PTCL the interpreted (the) parable

$03 \quad(0.5)$

$04 \mathrm{TE}$ : die drei: die ringparabel; the three the ring parable

$05 \quad(\cdot)$

(A) $06 \mathrm{TE}:$.h das heißt (.) der <va:ter> entspricht eben .h this means the father PTCL corresponds

(A) 07 auf der (.) bedeutungsebene etwas anderem, on the level of meaning to something different

$08 \quad(0.4)$

09 TE: nämlich was natürlich? that is to say what of course

$10(\cdot)$

(A) $11 \mathrm{TE}$ : wenns um re+ligiotnen gehen soll? bb if it's supposed to be about religions +......traises hand---------->

12 (0.7)

13 TE: bap+tiste, bb $-->+$

(C) 14 BB: gott,

(E) 15 TE: "eben. EBEN

*turns to blackboard--->

$16(0.1) *(0.3)$

te --->*writes on blackboard--->

17 TE: die *drei söHne,

the three sons

$\rightarrow$ th

$18 \quad(0.2)$

19 TE: sind dann die drei. (.) die gläubigen jeder religion. then are the three the believers of each religion

The teacher refers to a previous shared activity of interpreting in lines $01-04$, indexing that he presupposes shared knowledge about the discourse topic. ${ }^{18} \mathrm{He}$ continues with a declarative upshot formulation, prefaced by the inferential connective das heißt ("that means") (line 06). This could be understood as a known-answer question because the informational focus of the clause ("something different," line 07) is a placeholder: Students are to replace this underspecified reference to show their knowledge. After a gap, in which no student indicates readiness to respond, the teacher asks for specification (line 09). The sought-after information is again indexed to be known in common with the epistemic adverb natürlich ("of course").

\footnotetext{
${ }^{13}$ Shared knowledge is also implicitly ascribed by the modal particle ja (lines 01-02), which indexes common ground and evidence (Reineke, 2016).
} 
The anchor. When still no students raise their hands, the teacher adds a conditional clause (line 11), hinting at the domain of knowledge in which the answer can be found: wenns um religionen gehen soll? ("if it's supposed to be about religions"). The teacher asserts himself as being in $\mathrm{K}+-$ position, and this reflexively confirms his institutional role.

The confirmable. The answer gott ("god") (line 14) builds both on the hint as its inferential basis and on shared knowledge arising from prior work on the topic. The relevance of both sources is shown in the turn's placement: Baptiste already raises his hand when the first syllable of religionen (line 11) has been produced. The relationship between anchor and confirmable is between a domain of knowledge ("religion") and a state of affairs within it (God's position in this domain).

Eben (line 15) confirms Baptiste's answer as correct while indexing it as not new information. Eben closes the subtopic "metaphorical meaning of the father in the ring parable" and registers the result of its treatment. A teacher's eben can thus be understood to highlight the confirmed answer as now shared and as something to be retained. That the student's answer is "a building block supporting the next stage in the progression of the instruction sequence" (Margutti \& Drew, 2014, p. 448) is further evidenced by the teacher's bodily behavior: He turns around to record information on the blackboard (lines 15-17) and then builds his ensuing talk on this result (lines 17-19).

Extract 5 further highlights the connection eben establishes between the local sequence and a larger activity. Two sisters are painting a room together. Tamara (TZ) is helping Pauline (PZ), who has planned the project. In line 01, Tamara asks what will happen if they run out of paint. Pauline explains that she has already considered this problem (lines 03-04).

01 TZ: hey was is wenn die farbe uns ausgeht,

hey what happens if we run out of paint

02

$(0.4)$

(A) 03 PZ: des war ja auch >einer der gründe <

that was PTCL also one of the reasions

(A) 04 warum ich heute des anfangen wollde?

why I wanted to start this today

$05 \quad(\cdot)$

(A) 06 .h weiel, $(0.5) \cdot \mathrm{hh}(0.2)$ wenn wi:r (.) morgen streichen,h .h becau(a)se.hh if we paint tomorrow $h$

$07 \mathrm{TZ}: \mathrm{ja}$,

yeah

$08 \quad(0.7)$

(A) $09 \mathrm{PZ}$ : du fährst ja dann $E H=$

then you'il go PTCL anyway

(A) $10=>\uparrow$ wann fährst du zu deiner oma $\uparrow$ jetz g[enau:< when will you go to your grandma's PTCL e[ xactly]

(C) $11 \mathrm{TZ:}$ [am solnntag:

(E) $12 \mathrm{PZ}$ : genau; เeben. right EBEN

$13(0.2)$

$14 \mathrm{PZ}$ : .h und $i-($.$) ich hab nich gedacht$ . $h$ and $I$ I didn't think

15 >dass wirs wirklich heute schaffen < that we'd really make it today 
The anchor. Pauline shows in lines 03-09 and in the design of her question in line 10 (> $\uparrow$ wann fährst du zu deiner oma $\uparrow$ jetz genau< ["when will you go to your grandma's exactly"]), which indexes approximate knowledge of Tamara's travel dates, that she has knowledge "sufficient for all practical purposes" (Schütz, 1962, p. 12). In other words, she properly considered Tamara's plans when deciding to start the painting project heute ("today") (line 04) - that is, on a Friday. In her cut-off turn in line 09, Pauline uses two modal particles, $j a$ and $e h$, which both index shared knowledge and can mark a causal connection to another claim made in the context (Reineke, 2016).

The confirmable. Pauline recruits Tamara in co-constructing her argument by asking her to provide a date (line 10). The argument-confirming quality of the question is projectable via its sequential placement (launching an insertion sequence) and location within the larger argument (a reason is projected in line 06 and begun in line 09). Tamara's answer (am sonntag ["on Sunday"], line 11) completes Pauline's reason and thus confirms its correctness. This reasoning can be treated as collaboratively achieved.

Eben turn. Pauline's genau ("exactly") (line 12) ratifies Tamara's answer and targets a B-event. While Pauline clearly has independent knowledge, she does not confirm the answer's correctness from a position of epistemic superiority (the knowledge is in Tamara's domain) but rather marks its status as an expected corroboration of Pauline's argument (Betz, 2014). While genau closes the insertion sequence, eben acts as a hierarchical link in connecting the result of the local insertion sequence to an overarching activity and prior stance taken by Pauline (that the painting will require more than one day). The use of $e b e n$ is thus warranted by the fact that Tamara's information (line 11) corroborates the conclusion (cf. lines 14-15) on which Pauline's decision (lines 03-04) rests. Crucially, Pauline had already arrived at this decision before Tamara's reminder in line 11. Through indexing priority, eben accomplishes hierarchical argumentative linking of local to global concerns.

\section{Remote anchors}

Extract 6 shows that eben can also connect back across considerable discourse distance. It is taken from a telephone interaction between siblings Markus (MAR) and Ines (INE), who are discussing current German politics. The conversation was recorded after the federal elections of 1998, which resulted in a change in government from the center-right (led by the Christian Democratic Union, CDU) to the left (led by the Social Democrats, SPD). Markus and Ines are discussing the then-widely held view that Helmut Kohl (line 03), chairman of the CDU in 1998, had held on to power for too long and failed, in 16 years of chancellorship, to raise a strong successor.

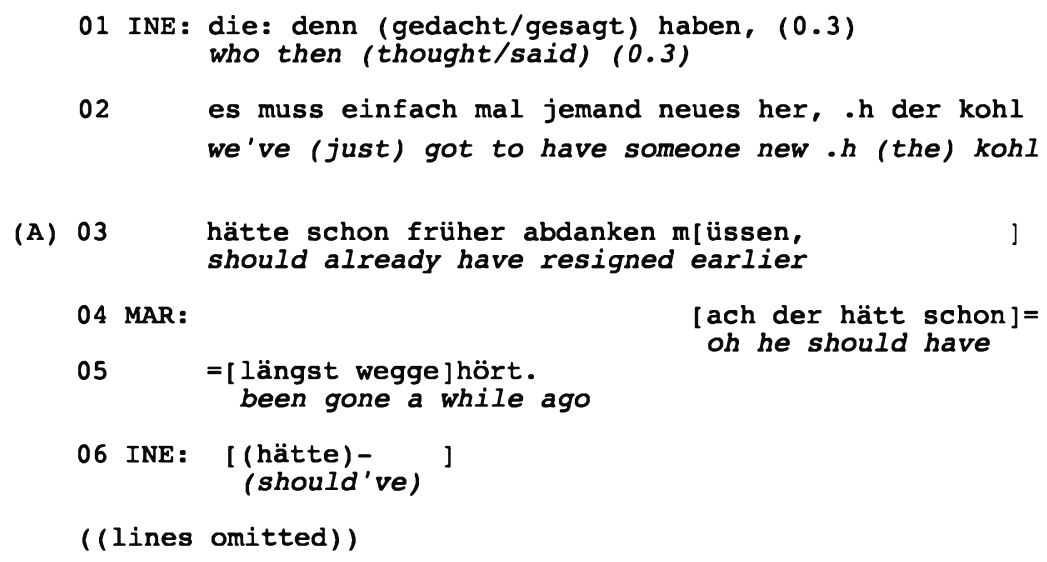


der hats $\mathbf{s}-<$ sechzehn jahre.

he's ((done)) it ((for)) sixteen years

18 INE: ja:_ja; .h und

yes yes ih and

(A) 19 hätte er früher jem- für seine(n) nachfolger gesorgt, had he earlier ((found)) some- made sure there's someone to suceed him

20

vielleicht war er ja $\mathrm{n}$ bischen zu machtgei:l,=ja? maybe he was PTCL a little too power hungry right

21 INE: . hh und dann hätte die es cee dee u vielleicht nich . $h$ h and then the $S C D U$ would maybe not have seen

22 solche einbußen erlitt[en. (des warn) halt] hier so= such losses (that was) PTCL like

23 MAR:

[ k. HHH !

]

24 INE: =die allgemeine- die allgemeine mei[nung.] the general- the general opinion here

25 MAR:

[JA. ]

26

$(0.2)$

Extract 6: abdanken ("resign") and nachfolger ("successor") [tel_AG_Oregon2B_8:00]

After line 26, Markus asserts (not shown) that, as a result of Kohl knowingly suppressing or ousting all potential successors, there was nobody to take over and lead the party to victory in 1998. Kohl himself had to run again (line 38). Ines confirms (line 40) and then claims prior knowledge of this (line 42) (Golato \& Fagyal, 2008). Markus elaborates on his earlier claim by naming an exception (lines 43-45, Schäuble) and then another supporting example (line 46, Späth). Schäuble and Späth are two other prominent CDU politicians.

38 MAR: da konnt er dann auch nicht mehr zurïcktreten:

(then) he couldn't step down any more either

39 MAR: . HH

40 INE: ja; $=$ yes

41 MAR: $=n j[a$.

PTCL

42 INE: $\quad[>j A[j a .<$

43 MAR: [der EINzige der dann war

the only one who then was

44

des wär der st- der schäuble gewe:sen?

that would have been (the) st (the) schäuble

45

.hhh und ähm hh und tschä: $f$ : das war ja:

. hhh and uhm hh and tshuh $f$ that was PTCL

der is ja leid=den spä:th hat er ja auch abgesägt. he is PTCL unfortunat(the) späth he PTCL also ousted

47

[.hh] [hhh ]

48 INE: [ja.][(0.2)]

yes 
49 MAR: und jetzt is (e:r/äh)

and now (he/uh) is

50

>jetzt hat er dann dn- den späth doch zurückgeho:lt. now he then brought back (th) (the) späth after all

(C) 51 .hh aber des wa:r (we:/je:) ja auch zu spät. .hh but that was (we/je) PTCL also too late

52 (0.2)

53 MAR: [ . HH] ((=sniff))

(E) 54 INE: [ja.] eben. (s)war zu spät. ${ }^{\circ}$ (oh/au) ${ }^{\circ} \uparrow$ hihihe.hh yes EBEN (t)was too late (oh/au) hihihe.hh

55 MAR: na ja;

PTCL

(oh well)

56 MAR: . hhh

Extract 6 continued: spät ("late") [17.tel.spaet_AG_Oregon2B_2:05]

In lines 49-50, Markus describes another move by Kohl and then adds the upshot that it was unsuccessful (zu spät ["too late"], line 51). The adjective spät is homophonous to the name of the politician referred to: Späth (line 50). Ines confirms Markus's assertion with ja and eben (line 54) and adds an agreeing repeat of the assessment (a wordplay) and laughter.

The anchor. The anchor for eben is distant from the confirmable. Ines produces two claims (lines 03, 19) attributed to public opinion-that is, to an authoritative position (lines 01, 22/ 24), but these also convey Ines's own view: that Kohl should have resigned and found a successor früher ("earlier").

The confirmable. In line 51, Markus assesses a political move by Kohl as aber des wa:r (we:/ je:) ja auch zu spät ("but that was (we/je) also too late"). Ja and auch index evidence and possibly also common ground (Reineke, 2016), thus not claiming epistemic authority and perhaps already linking this statement back to prior talk. Markus's assessment of Kohl's move as "too late" is related to Ines's two anchor statements (regarding actions Kohl should have performed "earlier") by implication.

The eben turn. With ja., Ines agrees with the prior assessment without doing any other epistemic positioning. With eben., Ines indexes epistemic priority, treating the confirmable (line 51) as a corollary of a more distant prior turn of hers (lines 03/19). This connection, however, remains implicit. Ines's subsequent other-repetition of $z u$ spät (line 54) highlights the humorous homophony of spät/Späth, thereby anchoring the subsequent laughter.

The next extract shows that the anchor for eben can be outside of the current conversation. Recall that a basic claim regarding eben is that the prior talk to which eben connects only becomes its anchor retrospectively, once eben has set in motion a process of reinterpretation, by which some prior talk is connected inferentially to the turn to which eben responds. To better represent this process, we first show the local context in which eben is embedded and then supply part of an interaction that took place one day earlier.

Extract 7 is also from our painting project. Having painted the wall, Pauline (PZ) removes strips of masking tape. The wall now looks plain white, and Tamara (whose gaze is on Pauline throughout the extract) assesses the results positively (line 01). Pauline responds with ja ("yep"). Adding eben, she treats Tamara's assessment as supporting a position she herself had taken earlier. 
Extract 7: streifen (“[brush]lines”) [126.av_FOLK_218_c654_16:45]

(C) $01 \mathrm{TZ}$ : nee=sieht doch cooler aus ohne die streifen; no ((it)) does look cooler without the lines

$02 \quad(0.2)$

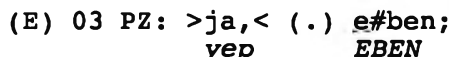

yep EBEN $\quad$ \#fig.1

$04 \quad(0.1)$

$05 \mathrm{PZ}$ : wusst ich auch:

I also knew ((that))

$06 \quad(0.4)$

$07 \mathrm{PZ}$ : jetzt +(ziehn wer) wieder einma: $1+$ now (we pull) once again

tpulls masking tape off wall+

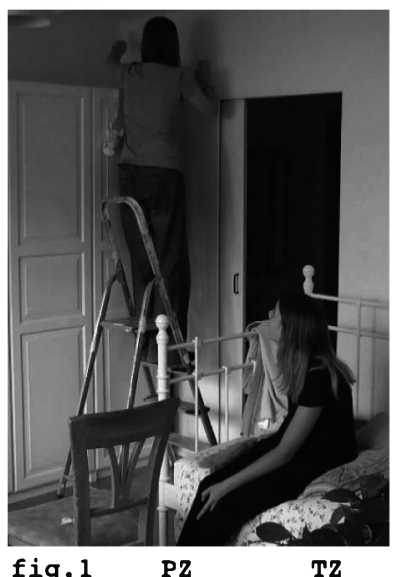

The anchor. There is no anchor in the same interaction. Instead, it is located in a discussion the two sisters had one day earlier. Tamara had used a paintbrush to paint a certain spot on the wall. Pauline had argued that the painting should be redone with a paint roller because a roller would make the result appear even (and not streifig ["streaky"], Extract 8, line 06). Pauline had later repainted the spot with the paint roller, leading to the result that is assessed positively by Tamara in Extract 7.

Extract 8: rolle ("roller") [126.av_FOLK_217_c639-650_19:40-19:53]

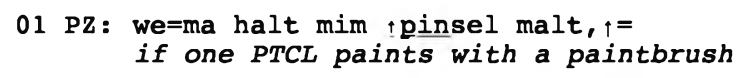

(A) $02=>\uparrow$ des mach ich nich so gerne weil< da: $\uparrow(0.3)$

$I$ don't like to do that so much because there

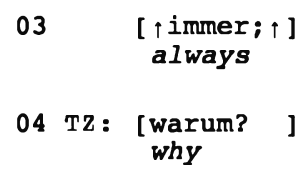

$05 \quad(0.3)$

(A) 06 PZ: de- des (.) wird dann so streifig irgendwie: (.) also: tha- that then becomes kind of streaky somehow (so)

$07 \quad(0.7)$

(A) $08 \mathrm{PZ}$ : mit der rolle siehts ${ }^{\circ}$ besser aus find ich; ${ }^{\circ}$ with the roller it looks better I find

$09 \quad(0.3)$

$10 \mathrm{PZ}: \operatorname{hhh}(0.5)+\mathrm{HHH} .+\quad \begin{aligned} & \text { okee: } ;=\mathrm{hh} \\ & \text { okay }\end{aligned}$

+sighs+ 
The confirmable. Although no related exchange had taken place before in the interaction, Tamara's assessment nee = sieht doch cooler aus ohne die streifen ("no ((it)) does look cooler without the lines") (Extract 7, line 01) is designed as counter to expectation. This is accomplished by the turn-initial response particle nee ("no"), which marks a change in one's own position, and the cognitive-epistemic modal particle doch (Diewald \& Kresić, 2010), which indexes a back-down from an earlier position ("use the paintbrush"). As a result, Tamara now aligns with Pauline's counterposition ("use the paint roller"). The anchor, produced by Pauline in the earlier encounter, is made salient again as common ground.

Eben. After a confirmation with a short glottalized ja ("yep"), Pauline's eben links back to her prior position and treats Tamara's (surprised) change in position as evidence for its validity. Pauline then expands her turn with wusst ich auch ("I also knew [that]") (line 05), which connects back to Tamara's assessment through analepsis and makes Pauline's claim to prior knowledge explicit. Wusst ich auch indexes that Pauline's painting preference rested on superior knowledge about a fact Tamara only realized by virtue of Pauline's action. It underscores that the confirmable is not offering anything new.

\section{Postpositioned evidence after eben}

The preceding extracts offered evidence for a three-part structure that eben invokes. Eben confirms on both a local and a global level and achieves the latter by linking the confirmable to a prior anchor (typically at some distance) and to the larger action trajectory. Our data suggest that this three-part structure is indeed the basic pattern of use. In 187 of 290 examples, eben links back to an anchor in earlier interaction, through which the eben speaker had already independently positioned herself. In 84 examples, eben speakers do not produce a prior anchor, at least not in the available data. ${ }^{19}$ In 74 of these, however, speakers add evidence after eben. We argue that in these latter examples, which result in extended eben turns, speakers perform a remedial move: They underpin a claim for which there were insufficient grounds and thereby show that eben indeed conveys a claim to independent positioning.

Consider Extract 9, taken from a dinner conversation. Bert and Leni are the hosts, Cora and Andi guests; the main dish prepared is Käsespätzle (line 05). Sie (line 04) refers to the hosts' daughter Tina, who is currently visiting friends in the town of Hanau. A small story unfolds, launched by Leni's description of her daughter's reaction to learning that Käsespätzle would be consumed in her absence. The punch line (Jefferson, 1978) is delivered in line 09 and expanded in line 14.

Extract 9: hanau oder käsespätzle 'hanau or cheese spaetzle' [16.av.spaetzle_Kaese.t5_M2.29_8.33]

01 LEN: und fliegt dann donnerstag. and then ((she)) flies ((out)) thursday

02 COR: mmhm. okee. mmhm okay

03 $(0.8)$

04 LEN: jA sie hat gleich so: ein gesicht gezogen PTCL she immediately made such a face

05 als sie gehört hat dass wir heute käsespätzle essen. when she heard that we'd be eating käsespätzle today

06 COR: . HH [ hhhh

] [*hmhmhm* $((=$ laughs $))]$

07 LEN : [*>hab ich gesagt< tja*]

((so)) I said (well)

08 AND:

*I/hand up, palm open*

len

[ hmm $=$ mh, *
*shakes head* ]

09 LEN : man [muss ] priori[täten] se[tzen im] leben.=ne?= one has to prioritize in life right

\footnotetext{
${ }^{19}$ The remaining 19 examples are discussed in section "Summary and discussion".
} 


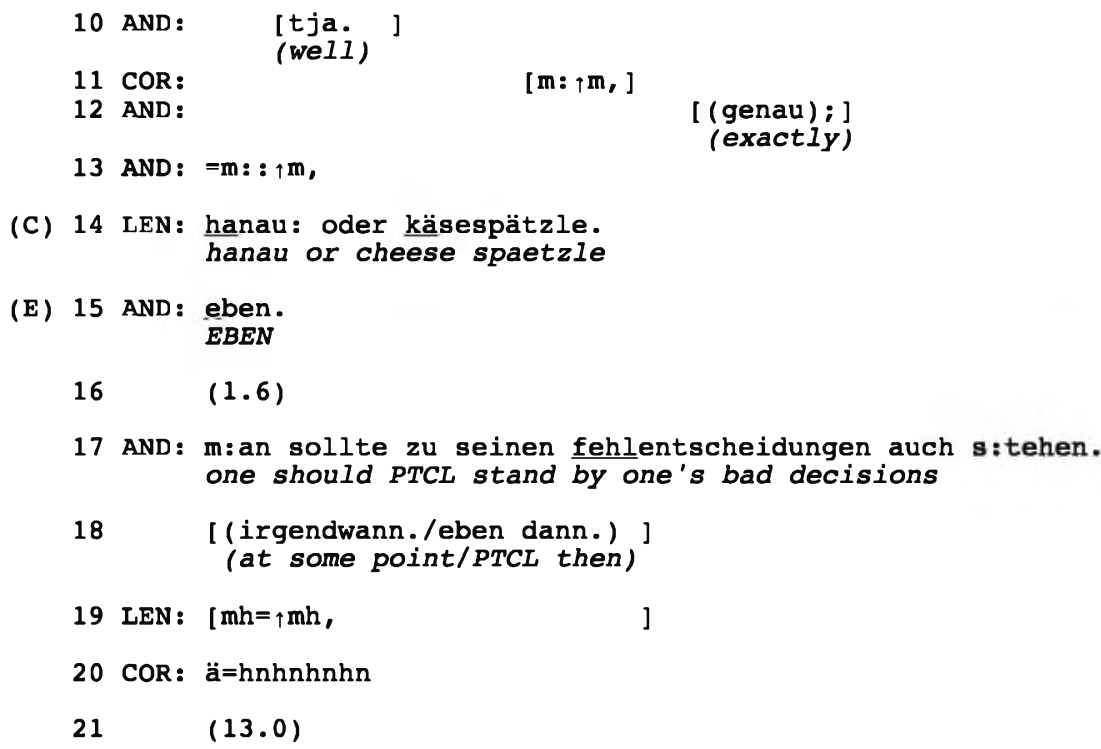

The confirmable. Leni introduces a self-quote in line 07. A palm-up open-hand gesture, tja, a head shake (line 08) and a commonsense expression (line 09) convey that the position she took in response to her daughter's complaint was an obvious one: Making choices in life is unavoidable, and this involves setting priorities. Andi, the main recipient of the punch line (line 09), produces response particles that index a position toward the matter (lines $08,10,12,13$ ), but his position is either not unambiguously inferrable or insufficient for Leni, as evidenced by Leni's expansion of the punchline: hanau: oder käsespätzle (line 14). Leni makes the two options her daughter had in the process of "prioritizing" (line 09) explicit, thus creating a second slot for a more substantial appreciation of the story (cf. Schegloff, 1996b, on recompleting turns), and specifically for an assessment of the daughter's decision.

Eben turn. If eben claims an inferential connection to a position communicated earlier, then its use in this extract is opaque, since there is no inferrable anchor for Andi's claim. A more distant anchor in a prior conversation is unlikely: Leni's story is about a very recent event, and it is reported and received as news.

Provision of additional evidence. The continuation of this sequence shows that a basis for anchoring eben in prior discourse is indeed noticeably missing. After a pause (line 16), possibly indicating coparticipants' problem with Andi's eben, Andi provides an account. Through parallel deontic framing with man muss ("one has to") (line 09) and man sollte ("one should") (line 17), this account links back to Leni's formulation of everyday wisdom (line 09). Just as in the cases of preceding anchors, postpositioned additional evidence does not repeat the confirmable but is inferentially related to it. By assessing the daughter's decision as fehlentscheidung ("bad decision") and using the modal particle auch to mark the prior utterance as already known or its reasoning as expected (Franck, 1980, pp. 210-11), Andi constructs a matching but independent assessment. This backs up what Andi's eben claims. Postpositioned evidence shows that a missing anchor for eben is treated as absent and needs to be supplied after eben.

A further observation about the types of accounts following eben: We do not have examples in which eben turns are followed by a repeat of what eben confirms. ${ }^{20}$ We take this as further support for the basic

\footnotetext{
${ }^{20}$ Extract 6, line 54 may look like a counterexample. This repetition, however, does not display a prior stance. Instead, it appreciates the wordplay by homophony in the prior speaker's turn (späth, line 50, spät, line 51) (cf. Golato, Betz, Taleghani-Nikazm, \& Drake, 2017 on assessment repeats in German).
} 
discourse-deictic function of eben. If eben invokes an independent prior positioning, then an other-repeat would not suffice to back up this claim. When the eben speaker has not first staked an independent claim, she needs to show independent knowledge through formulating post-eben evidence. A repeat does not demonstrate a connection; it merely claims it (Sacks, 1992, pt. II, pp. 141-142; cf. Betz et al., 2013). ${ }^{21}$ To be convincing, eben seems to necessitate a demonstration to provide more than what was already given by others.

While postevidence is mostly produced if an anchor is missing (at least in the data available to us), remote, or opaque, there are also cases in our data in which postevidence is provided despite the presence of an anchor in the immediate sequential context. An example is Extract 10 from a driving lesson. The instructor (RK) asks the student (PW) a known-answer question (lines 02-05) about how gearing up should be executed in a manual transmission car.

Extract 10: gas weg (“off the gas") [102.av_FOLK_171_c532_12:04]

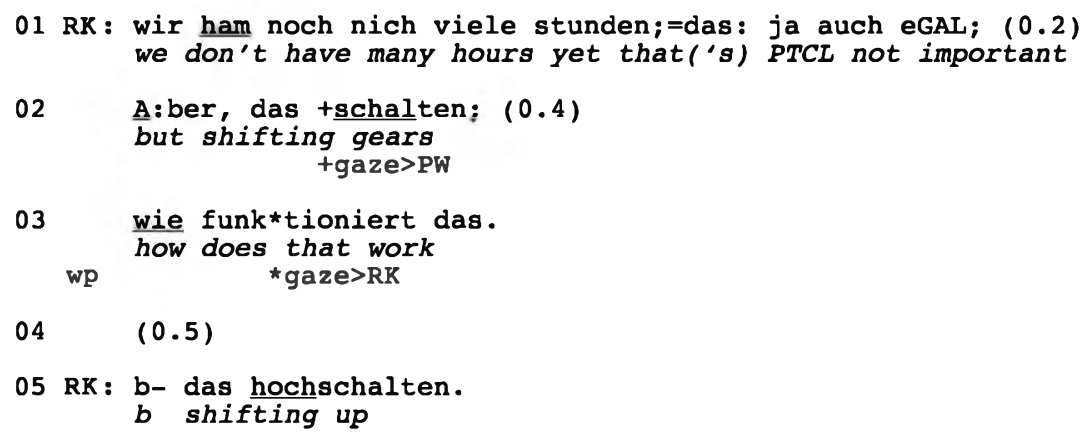

\footnotetext{
${ }^{21}$ We apply Sacks's conceptual distinction between demonstrating and claiming understanding to our analysis of claiming versus demonstrating an independent stance.
} 


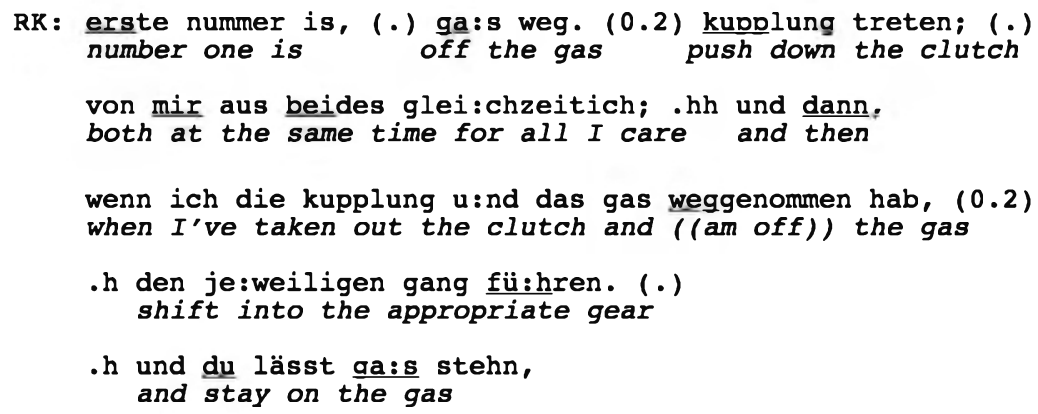

The student starts to answer the question by naming an action (kupplung treten ["push down the clutch"], line 07), which, however, is not the first step of the canonical procedure. The instructor starts other-repairing with $g a$ in overlap (line 08) but cuts himself off in favor of producing the rejection particle nee. The instructor's $g a$ is a partial realization of the first syllable of the correct first answer component given later, gas weg ("off the gas") (line 15), which the student provides immediately upon the instructor's other-repair plus rejection (line 10). In line 11, the instructor first produces ga again, then cuts off. This TCU-fragment projects confirmation of the student's prior turn by repetition, but it is aborted in favor of eben (line 13). In lines 15-19, the instructor adds an elaborate description of the whole procedure, which indexes his $\mathrm{K}+-$ status. He does not accept the student's self-correction in line 10 as sufficient and does not let him complete the projected description of the whole procedure. The student's initial failure is instead treated as evidence that the student is in need of explicit reeducation on the correct procedure. The confirmation by eben is produced in the third position of an IRE sequence (confirming the correctness of the last bit of information the student provided) and taken as point of departure for further teaching. The provision of postevidence with an identifiable anchor thus seems motivated by the pedagogical context. Moreover, the use of eben here is not only confirming but at the same time clearly indexing criticism of the student's lateness in realizing the correct first answer component.

\section{Summary and discussion of findings}

Eben confirms a prior turn, treating the position, information, or insight it offers as not new but evident and indisputable. In addition, it exhibits a double indexicality by relating confirmation of the prior turn to a position the eben speaker displayed in prior discourse. An eben speaker claims to have already independently held and displayed her position before the confirmable. Because eben necessitates positioning displays that validate the claim indexed by eben, it cannot be understood within the local sequence "confirmable-eben" alone.

In the majority of cases, the eben speaker has expressed her position in prior discourse in a way that she takes to be identifiable for the coparticipant. We called this the anchor. In these cases, eben operates retrospectively and can stand alone. The first pattern for the use of eben is:

(1) Preceding anchor (187 of 290 cases)
A. anchor
B. confirmable

A. eben

The anchor may directly precede the confirmable or be more remote. It is typically produced within the same stretch of topical talk in the same interaction. Extracts 7 and 8 show that an anchor can also be located in a previous encounter. 
If an anchor was not already produced or may not be identifiable for the recipient, using eben requires a subsequent position formulation. This formulation adds evidence for what was claimed with eben, thus fulfilling the interactional requirements for its use. The resulting second pattern is:

(2) Postpositioned evidence (135 of 290 cases)

B. confirmable

A. eben + evidence for position claimed

In $90.7 \%(263 / 290)$ of our cases, speakers produce a clear preceding or subsequent display of independent epistemic stance to be related to the confirmable. Table 1 provides an overview of the distribution of anchor and postpositioned evidence in the two patterns we observed in our collection.

Since a preceding anchor is present in the majority of cases $(187 / 290,64.5 \%)$ and postevidence is typically not furnished when an identifiable anchor has been produced (128/187, $68.4 \%$ of all instances with an anchor) but is overwhelmingly supplied when there is no localizable anchor $(74 / 84,88.1 \%$ of all instances without an anchor), we conclude that the postpositioned addition of evidence in pattern (2) is a remedial move. It deals with the lack of an intersubjectively recoverable anchor, thus validating the claim eben makes to an independent, prior positioning.

As Table 1 shows, both patterns also occur in combination. In 59 out of 187 cases $(31.6 \%$ of all instances with an identifiable anchor), an eben speaker produces an anchor but adds evidence. In these cases, the added talk is produced by expansion of the eben turn, not in a later turn, and the eben speaker initiates the expansion herself. Postpositioned evidence tends to be produced with a preceding anchor if the anchor is remote or if the inferential relationship between confirmable and anchor is opaque or complex and may not be understood. Mere claims of priority seem only possible with a preceding anchor (Extract $7-8,10$ ). When there is no anchor, at least some sort of paraphrase that may be taken to "go beyond the information given" (Bruner, 1957) by the confirmable is in order to warrant the claim to independence of position with eben (Extract 9).

Eben requires some position formulation and differs in this respect from the response particle genau and from modal particles indexing common ground (Fischer, 2007; Reineke, 2016). Although responsive eben often additionally draws on common ground concerning knowledge and evaluations, our analysis suggests that common ground is not enough to index a shared stance with eben. Rather, the speaker needs to deliver discursive in situ evidence of the position she claims to hold. Both anchors and postpositioned (remedial) demonstrations never simply repeat the confirmable; instead, they are inferentially related to it. They formulate a cause, a reason, a consequence, a similar event or property, a more abstract or a more specific position.

We have 10 out of 290 instances (3.5\%) in which neither a recoverable anchor nor postpositioned evidence is produced (see Table 1, not shown in the analysis section). Some of these cannot be further contextualized due to lack of data or recording quality issues, but in

Table 1. The Distribution of Anchor and Postpositioned Evidence $(N=290)$.

\begin{tabular}{lcccl}
\hline & anchor & ?anchor? & no anchor & \multicolumn{1}{c}{ extracts shown } \\
\hline no evidence $155(53.5 \%)$ & $128(44.1 \%)$ & $17(5.8 \%)$ & $10(3.5 \%)$ & $\begin{array}{l}\text { with anchor: } 2 \text { prüfungen, } 3 \text { huskytour, } 4 \text { ringparabel, } 5 \\
\text { farbe, } 6 \text { abdanken }\end{array}$ \\
evidence after eben $135(46.5 \%)$ & $59(20.4 \%)$ & $2(0.7 \%)$ & $74(25.5 \%)$ & $\begin{array}{l}\text { with anchor: } 7-8 \text { streifen, } 9 \text { gas weg } \\
\text { without anchor: } 9 \text { hanau oder käsespätzle }\end{array}$ \\
total: & $187^{\mathrm{a}}(64.5 \%)$ & $19(6.5 \%)$ & $84(29.0 \%)$ &
\end{tabular}

"This number is likely higher. We coded instances as "no anchor" or "?anchor?" if we could not locate a candidate for an anchor position in the available context. However, in some cases in the collection $(N=290)$, it was simply not possible to inspect the larger context (e.g., prior encounters between the same interactants, as is the case in Extract 7/8) due to lack of data availability or recording quality issues. Ten of the 19 unclear instances (marked as "?anchor?" in Table 1) are such examples, in which we could not inspect the prior talk extensively. The other examples are discussed later. 
others, accountability for the position eben claims may be relaxed due to institutional or epistemic considerations: Some instances are from teaching/testing contexts in which eben is produced by the teacher/examiner in third position to a known-answer question. In these cases, the institutionally predicated $\mathrm{K}+-$ position of the eben speaker may take the place of explicit epistemic positioning prior to eben. In other extracts in our collection, eben seems to connect the prior turn to common ground, e.g., a prior physical move in a board game that was visibly accessible to all participants.

By exhibiting double indexicality concerning both the confirmable and a (prior) position formulation of the eben speaker, eben works as a cohesive, hierarchical device. It treats the prior turn as local evidence for a position that the eben speaker almost always has already conveyed earlier in the discourse. This indexing function of eben can be used to imply criticism of the producer of the confirmable for their failure of correct interactional bookkeeping (cf. Brandom, 1998; Schegloff, 1991), i.e., for not having added to common ground what the eben speaker had already communicated before and what should have been obvious earlier (see Extracts 3, 7, 8 and 10). ${ }^{22}$

\section{Conclusion}

The response particle eben belongs to a set of linguistic resources that index inferential relationships between turns in social interaction (Deppermann, in press). Response particles that confirm a position are specialized in indexing the relevance of prior access, knowledge, or experience. Confirmation particles share certain dimensions of interactional organization: German genau, like eben, can index consensus while claiming a priori-and thus independent-knowledge/positioning. Our article highlights the unique ways in which confirmation particles differ in the types of retrospective orientation they establish - that is, in the basis for claiming independence. While genau conveys that a coparticipant "said exactly what the speaker could have said herself" (Willkop, 1988, p. 140, translated, emphasis added), eben claims that a coparticipant said exactly what the eben speaker did already say herself. In treating the interlocutor's prior turn as formulating a position that the eben speaker has already, and publicly, taken, eben fulfills a function not yet described for response tokens.

By indexing an inferential relationship between anchor and confirmable, eben instructs the recipient to identifiy the anchor and its inferential relation to the confirmable. Using eben as a response thus is a practice that builds on and indexes the relevance of interactional bookkeeping (Brandom, 1998; Schegloff, 1991), i.e., the tracking of the emergence of common ground in social interaction (Clark, 1992). It (re)establishes the claim to the epistemic priority of the eben speaker by cueing an inference about how the recipient's prior turn-the confirmable-follows from or supports some prior, independently stated position of the eben speaker-the anchor. Through this, eben "reminds" the recipient of her duty to correctly keep track of interactional histories, i.e., of when which position is publicly established (for the first time) by which participant to an interaction, and to credit epistemic rights accordingly. Using the response particle eben therefore can be seen as a grammaticalized practice that indexes the close connection between information management (common ground) and relationship management (identities and rights and duties vis-à-vis each other) in social interaction (cf. Enfield, 2013, pp. 188-206; Stevanović \& Peräkylää, 2014): It indexes relative epistemic rights to publicly displayed positions of participants in interactional relationships, while at the same time showing that intersubjectivity has been accomplished with respect to the issue in question.

Through the use of eben, a prior confirmable turn emerges as support or evidence for the eben speaker's own position. In establishing this argumentative relationship, eben ties the local prior turn to the larger discursive position of the eben speaker. This double indexicality of eben creates a hierarchical structure in which a local agreement is related back to an overarching question under

\footnotetext{
${ }^{22}$ We coded 25 examples as clearly having this criticizing dimension. The analysis of this aspect of eben is difficult, since it is not eben itself but rather other interactional features (prosody, commentary following eben, as in Extract 3) that make this dimension visible and thus accessible to analysis.
} 
discussion and is mobilized to serve as evidence for the intersubjective acceptance of the speaker's position. Eben thus conveys participants' sense of interactional history beyond the immediate, adjacent context. It shows how current, local action relates to what has been said earlier and what may still be pending to achieve intersubjective closure on shared positions.

\section{ORCID}

Emma Betz http://orcid.org/0000-0001-6372-7803

Arnulf Deppermann http://orcid.org/0000-0001-7575-8236

\section{References}

Barnes, S. (2011). Claiming mutual stance: On the use of that's right by a person with aphasia. Research on Language and Social Interaction, 44(4), 359-384. doi:10.1080/08351813.2011.619312

Barnes, S. (2012). On that's right and its combination with other tokens. Journal of Pragmatics, 44(3), 243-260. doi:10.1016/j.pragma.2011.11.004

Barth-Weingarten, D. (2011). Double sayings of German JA-More observations on their phonetic form and alignment function. Research on Language and Social Interaction, 44(2), 157-185. doi:10.1080/08351813.2011.567099

Betz, E. (2014, June). Confirming and agreeing: Different uses of responsive genau in German Paper presented at the . International Conference on Conversation Analysis, Los Angeles, CA.

Betz, E. (2015). Indexing epistemic access through different confirmation formats: Uses of responsive (das) stimmt in German interaction. Journal of Pragmatics, 87, 251-266. doi:10.1016/j.pragma.2015.03.018

Betz, E., Taleghani-Nikazm, C., Drake, V., \& Golato, A. (2013). Third-position repeats in German: The case of repairand request-for-information sequences. Gesprächsforschung, 14, 133-166. Retrieved from http://www.gespraechs forschung-online.de/fileadmin/dateien/heft2013/ga-betz.pdf

Bolden, G. (2006). Little words that matter: Discourse markers "so" and "oh" and the doing of other-attentiveness in social interaction. Journal of Communication, 56(4), 661-688. doi:10.1111/j.1460-2466.2006.00314.x

Bolden, G. (2008). "So what's up?": Using the discourse marker so to launch conversational business. Research on Language and Social Interaction, 41(3), 302-337. doi:10.1080/08351810802237909

Brandom, R. B. (1998). Making it explicit. Reasoning, representing, and discursive commitment. Cambridge, MA: Harvard University Press.

Bruner, J. (1957). Going beyond the information given. In H. Gruber, K. Hammond, \& R. Jessor (Eds.), Contemporary approaches to cognition (pp. 41-69). Cambridge, MA: Harvard University Press.

Clark, H. H. (1992). Arenas of language use. Chicago, IL: University of Chicago Press.

Deppermann, A. (in press). Inferential practices in social interaction: A conversation-analytic account. Open Linguistics.

Deppermann, A., \& Günthner, S. (2015). Temporality in interaction. Amsterdam, The Netherlands: John Benjamins.

Diewald, G., \& Kresić, M. (2010). Ein übereinzelsprachliches kontrastives Beschreibungsmodell für Partikelbedeutungen [A non-language-specific, contrastive model for describing the meaning of particles]. Linguistik Online, 44(10), 1-18. doi:10.13092/lo.44.400

Enfield, N. J. (2013). Relationship thinking: Agency, enchrony and human sociality. Oxford, England: Oxford University Press.

Fischer, K. (2007). Grounding and common ground: Modal particles and their translation equivalents. In A. Fetzer \& K. Fischer (Eds.), Lexical markers of common grounds (pp. 47-66). Amsterdam, The Netherlands: Elsevier.

Franck, D. (1980). Grammatik und Konversation [Grammar and conversation]. Königstein, Germany: Scriptor.

Gardner, R. (2001). When listeners talk: Response tokens and listener stance. Amsterdam, The Netherlands: John Benjamins.

Gardner, R. (2007). The right connections: Acknowledging epistemic progression in talk. Language in Society, 36(3), 319-341. doi:10.1017/s0047404507070169

Golato, A. (2010). Marking understanding versus receipting information in talk: Achso. and ach in German interaction. Discourse Studies, 12(2), 147-176.

Golato, A., \& Betz, E. (2008). German ach and achso in repair uptake: Resources to sustain or remove epistemic asymmetry. Zeitschrift Für Sprachwissenschaft, 27, 7-37. doi:10.1515/zfsw.2008.002

Golato, A., Betz, E., Taleghani-Nikazm, C., \& Drake, V. (2017). Repeated assessments in German. Unpublished manuscript.

Golato, A., \& Fagyal, Z. (2008). Comparing single and double sayings of the German response token ja and the role of prosody-A conversation analytic perspective. Research on Language and Social Interaction, 41(3), 1-30. doi:10.1080/08351810802237834 
Hayano, K. (2013). Territories of knowledge in Japanese conversation (Unpublished doctoral thesis). Radboud University Nijmegen, Nijmegen, The Netherlands.

Heinemann, T. (2016). Registering revision: The reduplicated Danish change-of-state token nå. Discourse Studies, 18 (1), 44-63. doi:10.1177/1461445615614131

Helbig, G. (1988). Lexikon deutscher partikeln [Encyclopedia of German particles]. Leipzig, Germany: Enzyklopädie.

Hepburn, A., \& Bolden, G. (2013). The conversation analytic approach to transcription. In J. Sidnell \& T. Stivers (Eds.), The handbook of conversation analysis (pp. 57-76). Boston, MA: Blackwell.

Heritage, J. (2016). On the diversity of "changes of state" and their indices. Journal of Pragmatics, 104, $207-210$. doi:10.1016/j.pragma.2016.09.007

Heritage, J. (2013). Epistemics in conversation. In J. Sidnell \& T. Stivers (Eds.), The handbook of conversation analysis (pp. 659-673). Boston, MA: Wiley-Blackwell.

Heritage, J. (1984). A change-of-state token and aspects of its sequential placement. In J. M. Atkinson \& J. Heritage (Eds.), Structures of social action (pp. 299-345). Cambridge, England: Cambridge University Press.

Heritage, J., \& Raymond, G. (2005). The terms of agreement: Indexing epistemic authority and subordination in assessment sequences. Social Psychology Quarterly, 68, 15-38. doi:10.1177/019027250506800103

Jefferson, G. (1972). Side sequences. In D. Sudnow (Ed.), Studies in social interaction (pp. 294-338). New York, NY: Free Press.

Jefferson, G. (1978). Sequential aspects of storytelling in conversation. In J. Schenkein (Ed.), Studies in the organization of conversational interaction (pp. 219-248). New York, NY: Academic.

Kendon, A. (2004). Gesture: Visible action as utterance. Cambridge, England: Cambridge University Press.

Küttner, U. (2016). That-initial turns in English conversation-An interactional linguistic investigation of two formats for designedly tying a current turn to a prior (Unpublished doctoral thesis). University of Potsdam, Potsdam, Germany.

Lutten, J. (1979). Die Rolle der Partikeln doch, eben und ja als Konsens-Konstitutiva in gesprochener Sprache [The role of the particles doch, eben, and ja in constituting consensus in spoken language]. In H. Weydt (Ed.), Die Partikeln der deutschen Sprache [Particles in the German language] (pp. 30-38). Berlin, Germany: DeGruyter.

Margutti, P., \& Drew, P. (2014). Positive evaluation of student answers in classroom instruction. Language and Education, 28(5), 436-458. doi:10.1080/09500782.2014.898650

Mazeland, H., \& Plug, L. (2010). Doing confirmation with ja/nee hoor: Sequential and prosodic characteristics of a Dutch discourse particle. In D. Barth-Weingarten, E. Reber, \& M. Selting (Eds.), Prosody in interaction (pp. 161188). Amsterdam, The Netherlands: John Benjamins.

McHoul, A. (1978). The organization of turns at formal talk in the classroom. Language in Society, 7(2), $183-213$. doi:10.1017/s0047404500005522

Mehan, H. (1979). Learning lessons: Social organization in the classroom. Cambridge, MA: Harvard University Press.

Oloff, F. (2017). Genau als redebeitragsinterne, responsive, sequenzschließende oder sequenzstrukturierende Bestätigungspartikel im Gespräch [Genau as turn-internal, responsive, sequence-closing or sequence-structuring confirmation particle in conversation]. In H. Blühdorn, A. Deppermann, H. Helmer, \& T. Spranz-Fogasy (Eds.), Diskursmarker im Deutschen: Reflexionen und Analysen [Discourse markers in German: Reflections and analyses] (pp. 207-232). Göttingen, Germany: Verlag für Gesprächsforschung. Retrieved from http://www.verlag-gespraechs forschung.de/2017/pdf/diskursmarker.pdf

Pomerantz, A. (1978). Compliment responses: Notes on the co-operation of multiple constraints. In J. Schenkein (Ed.), Studies in the organization of conversational interaction (pp. 79-112). New York, NY: Academic.

Proske, N. (2014). ' $h$ ach KOMM; hör AUF mit dem klEInkram. Die Partikel komm zwischen Interjektion und Diskursmarker [ ${ }^{\circ} \mathrm{h}$ oh come on; stop the pettiness: The particle komm (come on) between interjection and discourse marker]. Gesprächsforschung [Discourse and Conversation Analysis], 15, 121-160. Retrieved from http://www.gespraechsforschung-online.de/fileadmin/dateien/heft2014/ga-proske.pdf

Raymond, G. (2004). Prompting action: The stand-alone "so" in ordinary conversation. Research on Language and Social Interaction, 37, 185-218. doi:10.1207/s15327973rlsi3702_4

Reber, E. (2012). Affectivity in interaction. Amsterdam, The Netherlands: Benjamins.

Reineke, S. (2016). Wissenszuschreibungen in der Interaktion [Knowledge attributions in interaction]. Heidelberg, Germany: Winter.

Sacks, H. (1992). Lectures on conversation [1964-1972, 2 Vols.]. Oxford, England: Blackwell.

Schegloff, E. A. (1991). Conversation analysis and socially shared cognition. In L. Resnick, J. Levine, \& S. Teasley (Eds.), Perspectives on socially shared cognition (pp. 150-171). Washington, DC: American Psychological Association.

Schegloff, E. A. (1996a). Confirming allusions: Toward an empirical account of action. American Journal of Sociology, 104(1), 161-216. doi:10.1086/230911

Schegloff, E. A. (1996b). Turn organization: One intersection of grammar and interaction. In E. Ochs, E. A. Schegloff, \& S. Thompson (Eds.), Interaction and grammar (pp. 52-153). Cambridge, England: Cambridge University Press.

Schütz, A. (1962). Collected papers I: The problem of social reality. The Hague, The Netherlands: Martinus Nijhoff. 
Schwarz-Friesel, M. (2007). Indirect anaphora in text. A cognitive account. In M. Schwarz-Friesel, M. Consten, \& M. Knees (Eds.), Anaphora in text (pp. 3-20). Amsterdam, The Netherlands : John Benjamins.

Schwitalla, J. (2003). Gesprochenes Deutsch [Spoken German]. Berlin, Germany: Erich Schmidt.

Sorjonen, M.-L. (2001). Responding in conversation: A study of response particles in Finnish. Amsterdam, The Netherlands: John Benjamins.

Stevanović, M., \& Peräkylää, A. (2014). Three orders in the organization of human action: On the interface between knowledge, power, and emotion in interaction and social relations. Language in Society, 43, 185-207. doi:10.1017/ s0047404514000037

Stivers, T. (2004). "No no no" and other types of multiple sayings in social interaction. Human Communication Research, 30, 260-293. doi:10.1111/j.1468-2958.2004.tb00733.x

Stivers, T. (2005). Modified repeats: One method for primary rights from second position. Research on Language and Social Interaction, 38(2), 131-158. doi:10.1207/s15327973rlsi3802_1

Thompson, S. A., Fox, B. A., \& Couper-Kuhlen, E. (2015). Grammar in everyday talk: Building responsive actions. Cambridge, England: Cambrdige University Press.

Willkop, E.-M. (1988). Gliederungspartikeln im dialog[Structuring particles in dialogue]. Munich, Germany: Iudicium.

Wright, M. (2011). On clicks in english talk-in-interaction. Journal of the International Phonetic Association, 41(2), 207-229.

Zifonun, G., Hoffmann, L., \& Strecker, B. (1997). Grammatik der deutschen Sprache [Grammar of the German language]. Berlin, Germany: de Gruyter. 